\title{
Design And Validation Of An Instrument To Assess A Didactic Sequence Directed To Promote The Development Of Critical Thinking
}

\section{Rodríguez Sandoval, Marco Tulio ${ }^{1}$; Bernal Oviedo, Gianny²; Fuentes Fuentes, Luz Stella ${ }^{3}$; Pérez Cardona, Análida ${ }^{4}$; Pérez Peñalosa, Vanessa Del Carmen5; Anaya herrera, Jhon Edinson ${ }^{6}$}

${ }^{1}$ Master in New Technologies applied to education; ${ }^{2}$ Master in digital technologies applied to education; ${ }^{3}$ Doctor of Education; ${ }^{4}$ Master in Administration of Educational Institutions; ${ }^{5}$ Magíster en Desarrollo Social; ${ }^{6}$ Master in environmental management

Article History: Received:11 January 2021; Accepted: 27 February 2021; Published online: 5 April 2021

\begin{abstract}
The text responds to the validation of an instrument that has been designed to evaluate the quality of an intervention proposal aimed at promoting the development of critical thinking in students of the competence assessment diploma of the degree programs of the Caribbean University Corporation CECAR. The design was subjected to a process that began with the validation of the judges, obtaining data that were subjected to the protocol of Lawshe (1975) modified by Tristán (2008), which allowed calculating the content validity index of the instrument 0.829 or $82,9 \%$, which confirms the seven proposed dimensions. Also, some recommendations from the judges regarding the writing of some items were accepted. The instrument was then subjected to the process of statistical validity by doing a pilot test with 20 products, initially calculating Cronbach's alpha of 0.912 , which shows a high consistency of the construct items. Subsequently, the Guttman and Spearman-Brown reliability coefficients were determined, obtaining values of the coefficient of the two halves of the construct of 0.998 that show high reliability. And at the end, the goodness of fit test of the model was carried out, estimating the variance error, common variance and true variance, estimated common inter-element correlation, estimated reliability and estimation of unbiased reliability, obtaining values that demonstrate high reliability and internal consistency.
\end{abstract}

KEYWORDS: didactic, critical thinking, instrument

\section{INTRODUCTION}

One of the most important challenges for teachers today is to design curricular plans aimed at promoting the development of critical thinking in their students. It is clear that academic work must be focused on the formation of a citizen who thinks, feels and acts in a congruent way as demanded by the 21 st century society. There is still no clarity about the cognitive and metacognitive logic to implement, especially in a context that demands high levels of thinking from its students, such as university students.

For this reason, didactic models and evaluative instruments are desperately sought to accompany this training process. In other words, it seeks to model a scenario where the necessary skills are developed based on fundamentals such as this: Learning to think critically implies learning to reason better and use logical tools by verbally expressing the arguments that move us to make decisions and act. Perhaps for this reason, the argumentative line of critical thinking proposes a type of education based on argumentative, propositional and interpretive competences. In this way, it tries to promote a type of educational practice in which students learn to know how to justify, support, develop an idea, know how to value and consider various alternatives, convince someone of something and, in a particular way, also know how to counter-argue ( Martín and Barrientos, 2009, p.24).

Taking into account the above, and the demands of the macroproject entitled: Design of a didactic model using emerging technologies aimed at promoting the development of critical thinking in students, the CECAR research group designed a didactic sequence model aimed at promoting thought criticism of the students and a rubric to evaluate the quality of the same, based on the elements of critical thinking of Paul and Elder (2003). To carry out this work, the students of the diploma in competency assessment of the education programs of the Caribbean University Corporation CECAR were invited, who prepare an investigative monograph that has a diagnosis of a real situation in an educational institution of the basic level focused on at the level of critical thinking that a group of students has, an intervention proposal aimed at promoting the development of critical thinking and a post-test to evaluate the effectiveness of the strategy used. In order to assess the quality of these products, there must be instruments that are coherent with the model of the didactic sequence evaluated and relevant to their intentions. As 


\section{Rodríguez Sandoval,Marco Tulio'; Bernal Oviedo,Gianny²; Fuentes Fuentes, Luz Stella³; Pérez Cardona,Análida ${ }^{4}$; Pérez Peñalosa, Vanessa Del Carmen ${ }^{5}$; Anaya herrera, Jhon Edinson ${ }^{6}$}

the required instrument is not available, the research group intends to design and validate an instrument to assess a didactic sequence aimed at promoting the development of critical thinking in students.

\section{Theoretical bases that support the construction and validation of the rubric}

Teachers in their role as designers of curricular plans aimed at developing a competence, must have conceptual clarity about what to assume, the scenarios that must be used, the didactic and technological resources that must be articulated and the type of evaluation that must be applied. For this reason, it is considered that the creation of relevant scenarios and the way to evaluate them using instruments have to be articulated despite being processes that are independent. The articulation must be done, even if for the most part, from the same theoretical foundation, giving it the coherence necessary to evaluate both the structure and content of the scenario (intervention proposal) and the instrument that has been designed (Rubric). According to this statement, it is necessary to point out the following concepts: Critical thinking, elements of critical thinking and the skills that a critical thinker must possess, the above allows a coherent definition of the didactic sequence and the instrument to be used.

\section{Critical thinking:}

Authors such as Paul and Elder (2003) define critical thinking as a way of thinking about any topic, content or problem, in which the thinker improves the quality of his thought by taking over the inherent structures of the act of thinking and subjecting them to intellectual standards (p. 4). In addition, they define the essential elements that are required to promote critical thinking, including: Formulates vital problems and questions, with clarity and precision, accumulates and evaluates relevant information and uses abstract ideas to interpret that information effectively, reaches conclusions and solutions, being tested with relevant criteria and standards.

Also, Paul and Elder (2003) raise the elements of critical thinking: purpose of thought, question in question, information, interpretation and inference, concepts, assumptions, implications and consequences, point of view. Each of them can be defined as follows:

Table 1. Elements of critical thinking Paul and Elder (2003)

\begin{tabular}{|l|l|l|}
\hline$N^{\circ}$ & ELEMENT & DEFINITIÓN \\
\hline 1 & Purpose & $\begin{array}{l}\text { All reasoning has a purpose, that is, the author recommends starting from an } \\
\text { intentional plan, that plan must be clear, it must be focused on a real and } \\
\text { significant issue. }\end{array}$ \\
\hline 2 & $\begin{array}{l}\text { Question in } \\
\text { question }\end{array}$ & $\begin{array}{l}\text { All reasoning is an attempt to SOLVE a PROBLEM, SOLVE a QUESTION or } \\
\text { EXPLAIN). That is, starting from a problem situation that makes it possible to } \\
\text { demonstrate the scope of what is being solved. This will lead the student who is } \\
\text { going to be offered the didactic sequence with this element to think of a solution } \\
\text { from different points of view. }\end{array}$ \\
\hline 3 & Assumptions & $\begin{array}{l}\text { "All reasoning is based on ASSUMPTIONS", that is, some conjectures related to } \\
\text { the reasoning that arises are taken into account to determine whether they can } \\
\text { justify. This makes it possible to determine the relationship between the point of } \\
\text { view that is held and the fundamentals used. In the rubric, this section is related } \\
\text { to challenges, as it seeks to confirm or disprove hypotheses. }\end{array}$ \\
\hline 4 & Informatión & $\begin{array}{l}\text { "All reasoning is based on ASSUMPTIONS", that is, some conjectures related to } \\
\text { the reasoning that arises are taken into account to determine whether they can } \\
\text { justify. This makes it possible to determine the relationship between the point of } \\
\text { view that is held and the fundamentals used. In the rubric, this section is related } \\
\text { to challenges, as it seeks to confirm or disprove hypotheses. }\end{array}$ \\
\hline 5 & $\begin{array}{l}\text { Concepts and } \\
\text { ideas }\end{array}$ & $\begin{array}{l}\text { "All reasoning is expressed through CONCEPTS and IDEAS", clarity in the } \\
\text { conceptual aspects that are going to work, these must be precise, since they will } \\
\text { allow the design of the strategy and activities. }\end{array}$ \\
\hline
\end{tabular}




\begin{tabular}{|l|l|l|}
\hline 6 & $\begin{array}{l}\text { Inferences and } \\
\text { interpretations }\end{array}$ & $\begin{array}{l}\text { "All reasoning contains INFERENCES or INTERPRETATIONS", in order to } \\
\text { reach conclusions it is necessary to generate inferences from evidence in order to } \\
\text { find solutions. }\end{array}$ \\
\hline 7 & $\begin{array}{l}\text { Implications and } \\
\text { consequences }\end{array}$ & $\begin{array}{l}\text { "All reasoning has either an end or has IMPLICATIONS and } \\
\text { CONSEQUENCES". Everything you think about is built must lead to decision- } \\
\text { making, this is done according to a positive and negative assessment of what is } \\
\text { raised, taking into account the possible consequences. }\end{array}$ \\
\hline 8 & Point of view & $\begin{array}{l}\text { "All reasoning is done from a PERSPECTIVE." For this, the construction is } \\
\text { evaluated, it is related to the self-evaluation, the aspects to be improved are } \\
\text { determined. }\end{array}$ \\
\hline
\end{tabular}

Source: Own elaboration

Villarini (2006) defines critical thinking as "the capacity of thought to examine and evaluate itself, in terms of five dimensions. The capacity for critical thinking arises from metacognition "in this sense, the dimensions proposed by the author are: logical, substantive, contextual, dialogic and pragmatic. The logical dimension, seeks clarity in the concepts, coherence and reasoning argued; substantive, identifies the reality of the context, recognizes diversity of methods to approach reality and delves into the search for information that defines their problem; contextual, identifies weaknesses and strengths in the exposed approaches, recognizes the subjectivity of the opinions and concepts of difference of the different voices that intervene in the discourses; dialogic, the ability to examine oneself in relation to the thinking of others, to assume other points of view and to mediate between different thoughts; the pragmatics identifies in his thought the reason for this, identifies in the thought the belief systems and the obstacles that limit thought.

On the other hand, for Facione, good critical thinkers are defined based on what they do, how they do it and how they arrive at a synthesis; he concludes that critical thinking is "the process of intentional, self-regulated judgment" (2007, p.22). For this he proposes six steps: Identify the problem; define the context; list the options; analyze the reasons explicitly; list the reasons explicitly; self-regulation, which must be identified in any learning process that is intended to promote the development of critical thinking.

On the other hand, for Lazo \& Muñoz (2011) the development of critical thinking must have three basic elements, the context, the strategies and the motivations. The context requires responding in a reasoned way and consistent with the situation. Strategies are the set of procedures available to the person to operate on the knowledge that he has and those new. Finally, motivations refer to the link established by the subject with knowledge, that affective bond that moves her curiosity and invites the development of a positive attitude towards knowing (Santiuste et al., 2001). These elements are put into play when the person thinks critically, which is given by the desire to know, curiosity, and the desire for truth, making it possible for them to apply the strategies available to them in a particular context (p.84) .

\section{A didactic sequence promoting critical thinking}

The didactic sequence that is going to be evaluated in this section must have clarity in the concepts, coherence and reasoned arguments (Villarini, 2006). This allows determining that, to promote the development of critical thinking, it is necessary to evaluate the quality of the thoughts (reasoning) of the scenarios and the thinking achieved in the implementation of the curricular plan that is presented to students in the classroom, for which which Villarini (2006) states:

We know that in a classroom the development of thinking is being stimulated when the teacher poses the student - and guides him in his accomplishment tasks of building knowledge, solving problems, making decisions and communicating meaningfully. Helping the student to exercise and develop this intellectual capacity is the primary educational objective of teaching oriented to the development of thinking (p. 38). 


\section{Rodríguez Sandoval,Marco Tulio'; Bernal Oviedo,Gianny²; Fuentes Fuentes, Luz Stella³; Pérez Cardona,Análida ${ }^{4}$; Pérez Peñalosa, Vanessa Del Carmen ${ }^{5}$; Anaya herrera, Jhon Edinson ${ }^{6}$}

Consequently with the above, the teacher at the time of planning their course must account for the way in which the thinking skills that are articulated with the elements of thought are evidenced, therefore, great care must be taken of the skills that they are going to work for what attitudes are needed that allow guiding the process, that is, they must be in a logic that is in tune with the learning process and the development of these skills, concretizing in what different authors call sequence didactics of activities.

Regarding the term didactic sequence, it is necessary to make some clarifications to be able to apply it with the desired intention. It is a term that has been introduced by way of planning courses or learning units in today's education. It can be affirmed that the didactic sequence refers to the disposition that is given to the elements or components of a course, cycle or teaching-learning unit, with the purpose of favoring the educational process, in the achievement of the learning objectives or competitions. Likewise, the didactic sequence refers to the variety of linked educational activities, which allow an object of study to be approached in a different way. Consequently, for Pérez and Gardey (2016), the activities of a didactic sequence must have a common thread that facilitates the development of their learning in a coherent way for students. That is, disorder and chance do not fit in this design

Confirming this logic, Santolaria-Orrios, A. (2019), refers to the fact that the didactic sequence must have three principles: legitimacy, relevance and solidarity. That is, the choice of gender must have a reason for being, the proposed activities must be a function of the work of textual and linguistic forms and must not be activities dissociated from each other.

A didactic sequence are various activities that have a logical sense where the student will develop different cognitive actions that will allow him to achieve what is proposed by the teacher, as proposed by Díaz-Barriga:

The didactic sequence is the result of establishing a series of learning activities that have an internal order among themselves, with this part of the teaching intention to recover those previous notions that students have about a fact, link it to problematic situations and contexts real in order that the information that the student is going to access in the development of the sequence is meaningful. (Díaz-Barriga, 2015, p.4).

According to Tobón (2010) "In the competences model, the didactic sequences are a relevant methodology to mediate the learning processes within the framework of learning or reinforcing competences" (p.20), so when putting this into practice type of methodology should be considered appropriate activities and relevant resources to achieve the proposed goals.

It should be noted that the didactic sequences framed in the competencies model should not be constituted in a myriad of monotonous activities, but rather different activities should be intertwined that allow the student to train in a critical, reflective way and for daily living. In this sense, the didactic sequence will foster interest in students to learn and collaborate with each other in activities where each one will thus strengthen their abilities, skills and knowledge, thus generating cooperative learning, which Vygotsky raises.

The didactic sequence must be oriented to the development of critical thinking, it must contain the necessary tools (strategies, activities, techniques) that allow structuring a meaningful sequence that allows the learning of critical thinking skills. The elaboration of the sequence that promotes the development of critical thinking leads to understanding that teaching is above all modeling; the teacher is used as an example to imitate. That is why he has to be an example of a thinker: curious, objective, reflective, systematic, creative, critical, etc. (Villarini, 2006)

In synergy with the above, the promotion of critical thinking implies that the teacher must generate spaces that make it possible to promote learning for life, hence Villarini (1986b, 1987a, 1991a) proposes the exploration, conceptualization and application strategy as the key stages of any didactic sequence of activities. In this logic, it is possible that the teacher can pose problems, determine needs and make educational decisions in a practical, systematic, creative and critical way in relation to planning. The strategy allows organizing the learning process in phases that give relevance and activate the student's potential for intellectual growth, advance in the learning of 


\section{Design And Validation Of An Instrument To Assess A Didactic Sequence Directed To Promote The}

Development Of Critical Thinking

knowledge in light of the interests and needs of the students arising in the instructional process itself and also allows , organize the teaching process simultaneously as a process of evaluation and feedback.

\section{Design and validation of an instrument to assess critical thinking promoting scenarios}

There are many attributes that promote the development of higher-level thinking scenarios have. In their identification, common elements are found in the proposals of Paul and Elder (2006), Villarini (2006) and Tobón (2010) when considering problem situations as the starting point of any didactic sequence. For Paul and Elder (2006) it includes the following elements: Goal, problem situation, reference information, activities that imply analysis, interpretation and inferences or conclusions or solutions, own arguments with models, principles, theories, assumptions, implications and consequences.

According to the two previous statements, the role of the teacher would not focus on the application of a rigid method that leads to a certain product and therefore a certain development of the person, but rather to create or promote scenarios to teach thinking to the student. In this way, the teacher stops being a coach who only seeks the development of certain skills up to a higher level, to become a strategist who accompanies, motivates, provides feedback and continuously values the development of the student's superior thinking without neglecting the development of the other dimensions. Therefore, great care must be taken with the realization of a specific educational model, that is, in the design, implementation and evaluation of didactic sequences at all levels of schooling. In this sense, it is necessary to differentiate the clearly behavioral scenarios from the constructivists and these in turn from the social developmental ones, especially when in the third decade of the 21 st century, all of them are permeated by emerging technologies and by the challenges that the technology continually demands of them. use of all these advances in terms of substantial improvements in the school model.

Therefore, it is necessary to evaluate the design of a didactic sequence, that is, to review how the elements of thought are evidenced from the purpose of the course, competence, activities that allow the student to think, so that in this way they can produce new knowledge and ideas. To make a relevant and reliable assessment, the instruments that facilitate assessment must be designed, validated, applied and continuously evaluated. The expert academic community that works on the basis of significant advances in this matter must participate in this process.

\section{METHODOLOGY}

The study is based on the design and validation of an instrument that serves to assess a didactic sequence aimed at promoting critical thinking in students who take the diploma in Competency Assessment, taken as a degree option in undergraduate programs in education. The use of this instrument seeks to improve the quality of the intervention proposal that these students design, taking into account elements such as relevance, coherence, significance and innovation of the product. The rubric is based on the thought elements of Paul and Elder (2006), taken as central categories, with some adaptations that were made to adjust it to the challenges that the student must have to mobilize all the knowledge based on the realization of the homework. In its structure there are three performance levels and it is designed so that the user evaluates himself and can give feedback on his product and reach the highest level, thus improving the quality of the product. Validity and reliability are two criteria that every instrument must meet, and once submitted to the evaluation and judgment of judges, it can be used for the purpose for which it was created (Robles \& Rojas, 2015).

For the design and validation of the instrument, the protocol of Supó, J. (2013) was used, considering the following steps: Literature review, exploration of the concept, list of topics that it integrates, formulation of categories and items, selection and evaluation of the judges, application of the pilot test, application of the pilot test, reduction of categories, criteria or items according to the statistical results and finally refinement of the design.

After an exhaustive review of the related literature, a definition of the concept of the instrument to be designed was made, formulating the categories, criteria and levels. This instrument was designed based on the concept of didactic sequence (Villarini, 2006) and the elements of critical thinking proposed by Paul and Elder (1997). Next, this approximation was reached: 


\section{Rodríguez Sandoval,Marco Tulio ${ }^{1}$; Bernal Oviedo,Gianny²; Fuentes Fuentes, Luz Stella ${ }^{3}$; Pérez}

Cardona,Análida ${ }^{4}$; Pérez Peñalosa, Vanessa Del Carmen ${ }^{5}$; Anaya herrera, Jhon Edinson ${ }^{6}$

El paso siguiente consistió en el juicio de los jueces (expertos) basado en criterios como la suficiencia, pertinencia, claridad y precisión del instrumento que se estructuró de la siguiente manera:

Table 1. Dimensions of the construct

\begin{tabular}{|c|c|c|c|c|}
\hline DIMENSION & $\begin{array}{l}\text { OBSERVABLE } \\
\text { VARIABLE }\end{array}$ & INDICATOR & ITEMS & $\begin{array}{l}\text { TOTAL } \\
\text { ITEMS }\end{array}$ \\
\hline Diagnostic & Quality & $\begin{array}{l}\text { - Relevant information } \\
\text { - Articulated to the proposal } \\
\text { - Reliable information }\end{array}$ & $1,2,3$ & 3 \\
\hline Purpose & Goal & $\begin{array}{ll}\text { - } & \text { Skill focused } \\
\text { - } & \text { Contains the strategy } \\
\text { - } & \text { Achievable } \\
\end{array}$ & $4,5,6$ & 3 \\
\hline $\begin{array}{l}\text { Problem } \\
\text { situation }\end{array}$ & $\begin{array}{l}\text { Contextualization } \\
\text { of the proposal }\end{array}$ & $\begin{array}{l}\text { - } \quad \text { Relationship to a context problem } \\
\text { - } \quad \text { Raises a situation to be questioned } \\
\text { - } \quad \text { Submit a statement or question }\end{array}$ & $7,8,9$ & 3 \\
\hline Challenge & $\begin{array}{l}\text { Resolution of a } \\
\text { problem }\end{array}$ & $\begin{array}{l}\text { - Diagnosis of needs } \\
\text { - Confirms or disproves hypotheses } \\
\text { - } \quad \text { Focused on solving the problem }\end{array}$ & $\begin{array}{l}10,11, \\
12\end{array}$ & 3 \\
\hline $\begin{array}{l}\text { Reference } \\
\text { information }\end{array}$ & $\begin{array}{l}\text { Reliability of the } \\
\text { information used } \\
\text { (sources) }\end{array}$ & $\begin{array}{ll}\text { - } & \text { Dependable } \\
\text { - } & \text { Updated } \\
\text { - } & \text { Referenced }\end{array}$ & $\begin{array}{l}13,14, \\
15\end{array}$ & 3 \\
\hline Analysis & $\begin{array}{l}\text { Activities that } \\
\text { require } \\
\text { information } \\
\text { analysis }\end{array}$ & $\begin{array}{l}\text { - } \quad \text { Comprehensive reading activities } \\
\text { - } \quad \text { Activities to organize information } \\
\text { - }\end{array}$ & $\begin{array}{l}16,17, \\
18\end{array}$ & 3 \\
\hline $\begin{array}{l}\text { Interpretatio } \\
\text { n and } \\
\text { inference }\end{array}$ & $\begin{array}{l}\text { Conclusions } \\
\text { arising from the } \\
\text { analysis or debate }\end{array}$ & $\begin{array}{ll}\text { - } & \text { Activities to evaluate arguments } \\
\text { - } & \text { Decision-making activities } \\
\text { - } & \text { Activities to conclude or propose }\end{array}$ & $\begin{array}{l}19,20, \\
21\end{array}$ & 3 \\
\hline
\end{tabular}

This table shows the operationalization of the Evaluation construct of an intervention proposal aimed at promoting critical thinking, considering its 7 dimensions, and the observable variables and indicators with their respective items, which were included in the measurement instrument put to use. consideration of the experts (initial construction, prior to the evaluation by the group of experts). Source: Research Group elaboration

Each of the experts was provided with an instrument, which included the indications and the conceptual definition of the construct, in addition to the essential, useful but non-essential and non-essential endpoints, so that the subject could evaluate the level of importance of each of the items. Subsequently, the content validity ratio (CVR and CRV ') was determined for each of the items, using the equations described in Lawshe's model; In addition, the Content Validity Index (CVI) was calculated. In equation 1, the formula to determine the content validity ratio for each item (CVR) is shown according to the Lawshe (1975) model, while in equation 2, the formula to determine the validity ratio is shown of content for each item according to the model of Lawshe (1975) modified by Tristán (2008), finally, equation 3 , determines the content validity index..

$C V R=\frac{\mathrm{n}_{\mathrm{e}} \mathrm{N} / 2}{\mathrm{~N} / 2}$ Equation used to calculate the content validity ratio for each item

CVR' $=\frac{\mathrm{CVR}+1}{2}$

Where: $\mathrm{CVR}=$ The content validity ratio for each item $\mathrm{N}=$ total number of experts Equation used to calculate the content validity ratio for each item (modified Lawshe Model) 
$C V I=\frac{\sum_{i=1}^{M} C V R i}{\mathrm{M}}$

Where: $C$ VRi $=$ Content validity ratio of the acceptable items according to the Lawshe criterion $\mathrm{M}=$ Total of acceptable items in the instrument Equation used to calculate the global validity of the instrument

The content validity ratio (CVR) values for each of the items are shown in Table 4.

\begin{tabular}{|c|c|c|c|c|c|c|}
\hline Dimension & Ítems & Essential & $\begin{array}{l}\text { Helpful but } \\
\text { not } \\
\text { essential }\end{array}$ & $\begin{array}{l}\text { Not } \\
\text { essensial }\end{array}$ & CVR & $\mathrm{CVR}^{\prime}$ \\
\hline \multirow[t]{3}{*}{ Diagnostic } & 1 & 8 & 1 & 0 & 0,777 & 0,888 \\
\hline & 2 & 7 & 2 & 0 & 0,555 & 0,777 \\
\hline & 3 & 6 & 2 & 1 & 0,332 & 0,666 \\
\hline \multirow{3}{*}{ Purpose } & 4 & 8 & 1 & 0 & 0,777 & 0,888 \\
\hline & 5 & 8 & 1 & 0 & 0,777 & 0,888 \\
\hline & 6 & 7 & 2 & 0 & 0,555 & 0,777 \\
\hline \multirow{3}{*}{$\begin{array}{l}\text { Problem } \\
\text { situation }\end{array}$} & 7 & 8 & 1 & 0 & 0,777 & 0,888 \\
\hline & 8 & 7 & 1 & 1 & 0,555 & 0,777 \\
\hline & 9 & 8 & 1 & 0 & 0,777 & 0,888 \\
\hline \multirow[t]{3}{*}{ Challenge } & 10 & 7 & 2 & 0 & 0,555 & 0,777 \\
\hline & 11 & 8 & 1 & 0 & 0,777 & 0,888 \\
\hline & 12 & 7 & 2 & 0 & 0,555 & 0,777 \\
\hline \multirow{3}{*}{$\begin{array}{l}\text { Reference } \\
\text { information }\end{array}$} & 13 & 7 & 1 & 1 & 0,555 & 0,777 \\
\hline & 14 & 8 & 1 & 0 & 0,777 & 0,888 \\
\hline & 15 & 7 & 2 & 0 & 0,555 & 0,777 \\
\hline \multirow[t]{3}{*}{ Analysis } & 16 & 7 & 2 & 0 & 0,555 & 0,777 \\
\hline & 17 & 8 & 1 & 0 & 0,777 & 0,888 \\
\hline & 18 & 8 & 1 & 0 & 0,777 & 0,888 \\
\hline \multirow{3}{*}{$\begin{array}{l}\text { Interpretation } \\
\text { and inference }\end{array}$} & 19 & 8 & 1 & 0 & 0,777 & 0,888 \\
\hline & 20 & 7 & 2 & 0 & 0,555 & 0,777 \\
\hline & 21 & 8 & 1 & 0 & 0,777 & 0,888 \\
\hline SUM & & 157 & 29 & 3 & 14,541 & 17,427 \\
\hline CVI GLOBAL & & & & & 0,692 & 0,829 \\
\hline ITEMS CVI & & & & & & 0,829 \\
\hline
\end{tabular}

Elaboration: Research group

The results show that most of the items are considered acceptable, according to the criteria of Lawshe (1975) modified by Tristán (2008), given that the values exceed the minimum cut-off point of 0.666; It can also be seen that the global validity index is 0.829 or $82.9 \%$, while the validity index of the items considered as acceptable is 0.829 or $82.9 \%$, with which it can be said that all are acceptable, and that the seven dimensions are confirmed as previously proposed.

When analyzing the reliability of a rubric, the internal consistency of the instrument was studied, and more specifically measurements of the homogeneity of the construct being measured. This approach arises from the classical theory of reliability and is mainly based on Cronbach's $\alpha$ coefficient and inter-item correlations. In the present case, the reliability analysis was carried out using the SPSS program, providing statistics that include the number of cases, the number of elements, and reliability estimates. The first statistic determined is the Cronbach coefficient of the whole instrument is 0.912 , for dichotomous data, this is equivalent to the Kuder-Richardson coefficient (KR). This value highlights the high consistency of the internal structure of the instrument (Morales, 


\section{Rodríguez Sandoval,Marco Tulio ${ }^{1}$; Bernal Oviedo,Gianny²; Fuentes Fuentes, Luz Stella ${ }^{3}$; Pérez}

Cardona,Análida ${ }^{4}$; Pérez Peñalosa, Vanessa Del Carmen ${ }^{5}$; Anaya herrera, Jhon Edinson ${ }^{6}$

2006), and indicates conceptual similarity between the items in the rubric, or the existence of a single, very clear factor, which highlights the assessment of competence.

Table 2. Cronbach's alpha coefficient

\section{RELIABILITY}

\begin{tabular}{|c|c|c|c|}
\hline \multicolumn{4}{|c|}{ SCALE: ALL VARIABLES } \\
\hline \multicolumn{4}{|c|}{$\begin{array}{l}\text { DATA PROCESSING SUMMARY } \\
\text { DATA }\end{array}$} \\
\hline \multirow[t]{3}{*}{ CASES } & Valid & 19 & 100,0 \\
\hline & Excluded $^{\mathrm{a}}$ & 0 &, 0 \\
\hline & Total & 19 & 100,0 \\
\hline
\end{tabular}

a. Delete by list is based on all variables in the procedure

\begin{tabular}{lc}
\hline & RELIABILITY STATISTICS \\
\hline Alfa de Cronbach & No. of elements \\
\hline $\mathbf{0 , 9 1 2}$ & 21 \\
\hline & Source: research group. Procedure performed with SPSS.
\end{tabular}

Source: research group. Procedure performed with SPSS.

By the value obtained from the Cronbach coefficient (0.912), a high consistency between the items of the instrument is demonstrated.

The second statistic is based on the two halves model. In this model, the scale is divided into two parts and the correlation between these parts is examined. The reliability coefficients of two Guttman halves, Spearman-Brown reliability (equal and unequal length) were determined, which appear below.

Table 3. Guttman and Spearman-Brown reliability coefficients

\begin{tabular}{|c|c|c|c|}
\hline \multirow[t]{5}{*}{ Alfa de Cronbach } & \multirow[t]{2}{*}{ Part 1} & Valor & $\mathbf{0 , 7 1 0}$ \\
\hline & & $\mathrm{N}^{\circ}$ of elements & $11^{\mathrm{a}}$ \\
\hline & \multirow[t]{2}{*}{ Part 2} & Valor & 0,879 \\
\hline & & $\mathrm{N}^{\circ}$ of elements & $10^{\mathrm{b}}$ \\
\hline & \multicolumn{2}{|c|}{ Total number of elements } & 21 \\
\hline \multicolumn{3}{|c|}{ Correlation between forms } & 0,998 \\
\hline \multirow{2}{*}{\multicolumn{2}{|c|}{ Spearman-Brown coefficient }} & Equal length & 0,999 \\
\hline & & Uneven length & 0,999 \\
\hline \multicolumn{3}{|c|}{ Guttman's coefficient of two halves } & 0.932 \\
\hline \multicolumn{4}{|c|}{$\begin{array}{l}\text { a. The elements are: Diagnosis, Diagnosis, Diagnosis. Purpose, purpose, purpose, problem situation, } \\
\text { problem situation, problem situation, challenge, challenge. } \\
\text { b. The elements are: challenge, challenge, reference information, reference information, reference } \\
\text { information, analysis, analysis, analysis, interpretation and inference, interpretation and inference, } \\
\text { interpretation and inference. }\end{array}$} \\
\hline
\end{tabular}

Source: SPSS research-analysis group

The third statistic is based on the strict Parallel and Parallel model: goodness-of-fit test of the model, estimates of error variance, common variance and true variance, estimated common inter-element correlation, estimated reliability, and estimation of unbiased reliability.

Table 4. Kindness of fit test of the model

TEST OF KINDNESS OF MODEL FIT

CHI-CUADRADO

Logarithm of the determinant Unconstrained matrix

\begin{tabular}{lr} 
VALOR & $-476,413$ \\
\hline Gl & 41 \\
\hline Sig & 1,000 \\
\hline Unconstrained matrix &, 000 \\
\hline
\end{tabular}


Design And Validation Of An Instrument To Assess A Didactic Sequence Directed To Promote The Development Of Critical Thinking

\begin{tabular}{lr}
\hline of & \multicolumn{1}{c}{ Restricted matrix } \\
\hline Under the strictly parallel model assumption & $-30,630$ \\
\hline \multicolumn{1}{c}{ RELIABILITY STATISTICS } \\
\hline Common Media & 0,750 \\
\hline Common variance & 0,198 \\
\hline True variance & 0,187 \\
\hline Error variance & 0,011 \\
\hline Correlation between common elements & 0,940 \\
\hline Scale reliability & 0,992 \\
\hline Scale reliability without bias & 0,993 \\
\hline
\end{tabular}

Source: Research Group-SPSS Analysis

Due to the values obtained from the reliability statistics shown in the previous table, the construct has high consistency and reliability without bias. Another attribute that is reflected in the set of statistical descriptors obtained from the evaluation of the proposed instrument is that it is the product of the theory that underpins the structure of the didactic sequence (Paul and Elder, 2003; Villarini, 2006), designed to promote the development of critical thinking in students, demonstrating its coherence and relevance.

\section{CONCLUSIONS}

El presente estudio ha mostrado que la rúbrica para la competencia «Diseño de una propuesta de intervención para promover el desarrollo del pensamiento crítico» puede aplicarse de forma válida y fiable para la evaluación de los proyectos elaborados por los estudiantes del diplomado en evaluación por competencias de los programas de Licenciatura en Educación de CECAR. A nivel práctico, este trabajo tiene importantes implicaciones para el profesorado involucrado en la evaluación del aprendizaje orientado a proyectos. A nivel académico, se evidencia la necesidad de revisar cualquier instrumento de evaluación si se pretende aplicar en contextos distintos a los que fueron diseñados. Tal y como se ha descrito anteriormente, la fiabilidad de una rúbrica no es inherente a sí misma, sino a las puntuaciones en base a las cuales se ha validado.

By the value obtained from the Cronbach coefficient (0.912), a high consistency between the items of the instrument is demonstrated. This shows that the items measure the same theoretical concept and that the test is reliable.

\section{BIBLIOGRAPHY}

1. Campo-Arias A., Herazo E. Y Oviedo H. Análisis de factores: fundamentos para la evaluación de instrumentos de medición en salud mental. Rev. Colomb. Psiquiat., vol. 41 / No. 3 / 2012

2. Díaz-Barriga, A. (2011). Competencias en educación. Corrientes de pensamiento e implicaciones para el currículo y el trabajo en el aula. Revista Iberoamericana de Educación Superior (RIES), vol. II, (5), 3-24, Disponible en http://ries.universia.net/index.php/ries/article/view/126

3. Díaz-Barriga, Á. (2013). Secuencias de aprendizaje. ¿Un problema del enfoque de competencias o un reencuentro con perspectivas didácticas? Profesorado. Revista de Currículum y Formación de Profesorado, vol. 17, núm. 3, septiembre-diciembre, 2013, pp. 11-33 Universidad de Granada, España

4. Facione, P. A. (2007). Pensamiento Crítico: ¿Qué es y por qué es importante? Recuperado el 17 de mayo de 2017 desde http://eduteka.icesi.edu.co/pdfdir/PensamientoCriticoFacione.pdf

5. Fernández-Marchesi N., (2016). Proyecto AREMUS. Manual de elaboración de secuencias didácticas para la enseñanza de las Ciencias Naturales. Universidad Nacional de Tierra del Fuego y Universidad de Buenos Aires (Argentina) Disponible en: https://www.researchgate.net/publication/336073940

6. González-Barajas, Ma., Kaplan-Navarro, J., Reyes-Osua, G., y Reyes-Osua, M. (2010). La secuencia didáctica, herramienta pedagógica del modelo educativo ENFACE. Universidades, (46), 27-33. Disponible en: https://www.redalyc.org/articulo.oa?id=373/37318636

7. Guzmán-Cedillo, Y. I. (2017). Diseño Y Confiabilidad De Una Rúbrica Para Evaluar Infografías Didácticas. Enseñanza\&Teaching, 35(2),17-36.

doi:http://dx.doi.org.ezproxy.cecar.edu.co:8080/10.14201/et20173521736 
Rodríguez Sandoval,Marco Tulio ${ }^{1}$; Bernal Oviedo,Gianny²; Fuentes Fuentes, Luz Stella ${ }^{3}$; Pérez Cardona,Análida ${ }^{4}$; Pérez Peñalosa, Vanessa Del Carmen ${ }^{5}$; Anaya herrera, Jhon Edinson ${ }^{6}$

8. Lazo, L., \& Muñoz, H. H. (2011). Aplicación de un modelo de intervención pedagógica que desarrolla estrategias de pensamiento crítico para estudiantes de carreras del área de las ciencias. Diálogos educativos, (21), 81-97

9. Malagón, V (2018). Infraestructura: Clave de la calidad de la educación. Artículo de opinión de la Revista Dinero. Recuperado de https://www.dinero.com/opinion/columnistas/articulo/infraestructura-es-clave-encalidad-de-educacion-por-victor-malagon/260702

10. Martín, A. y Barrientos, O. (2009) Los dominios del pensamiento crítico: una lectura desde la teoría de la educación. Teoría de la Educación, 21 (2), 19-44. Recuperado de: http:// revistas.usal.es/index.php/11303743/article/download/7150/7215.

11. Medina-Vidaña, E. Y Tobón, S (2010). Formación integral y competencias. Pensamiento complejo, currículo, didáctica y evaluación, 3a ed., Centro de Investigación en Formación y Evaluación CIFE, Bogotá, Colombia, Ecoe Ediciones, 2010. Revista Interamericana de Educación de Adultos, 32 (2), 90-95. Disponible en: https://www.redalyc.org/articulo.oa?id=4575/457545095007

12. Paul, R. \& Elder, L. (2003). La mini-guía para el pensamiento crítico. Conceptos y herramientas.

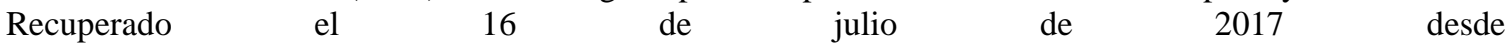
https://www.criticalthinking.org/resources/PDF/SPConceptsandTools.pdf

13. Pérez Porto, J., \& Gardey, A. (2016). "Definición de Secuencia Didáctica: Qué es y concepto. Obtenido de https://definicion.de/secuencia-didactica/

14. Robles-Garrote, P. y Rojas, M. D. C. (2015). La validación por juicio de expertos: dos investigaciones cualitativas en Lingüística aplicada. Revista Nebrija de Lingüística Aplicada (2015) 18.

15. Salazar-Gómez, Elizabeth; Tobón, Sergio; Juárez-Hernández, Luis G. (2018)Diseño Y Validación De Una Rúbrica De Evaluación De Las Competencias Digitales Desde La Socioformación. Apuntes Universitarios. Revista de Investigación, vol. 8, núm. 3, 2018 Universidad Peruana Unión, Perú Disponible en: http://www.redalyc.org/articulo.oa?id=467657107002

16. Santolaria Órrios, A. (2019). La secuencia didáctica: Un instrumento para escribir textos en educación infantil. Didáctica: $\quad$ Lengua $\quad y \quad$ Literatura, 31, 285-302. doi:http://dx.doi.org.ezproxy.cecar.edu.co:8080/10.5209/dida.65953

17. Supó, J. (2013). Cómo validar un instrumento - La guía para validar un instrumento en 10 pasos Hecho el depósito legal en la Biblioteca Nacional del Perú. N 2012-04073 ISBN: 1492278904 ISBN-13: 9781492278900. Disponible en: http://www.cua.uam.mx/pdfs/coplavi/s_p/doc_ng/validacion-de-instrumentosde-medicion.pdf

18. Tobón, S.J. Pimienta, J. García (2010). Secuencias didácticas: aprendizaje y evaluación de competencias. México: Pretince-Hall.

19. Vargas Salgado M. et al., (2016). Validez De Contenido De Un Instrumento De Medición Para Medir El Liderazgo Transformacional. Universidad Autónoma de Ciudad Juárez, Universidad Popular Autónoma del Estado de Puebla. RGN $\bullet$ Vol. $4 \downarrow$ No. $1 \downarrow 2016$ Revista Global De Negocios $\downarrow$ Volumen $4 \downarrow$ Numero $1 \downarrow$ 2016

20. Villarini, A. R. (2003). Teoría y pedagogía del Pensamiento Crítico. Perspectivas Psicológicas, pp. 3-4, 3542. 